\title{
ВЛИЯНИЕ РАЗЛИЧНЫХ ВАРИАНТОВ ЛЕЧЕНИЯ МОЧЕВОЙ ИНФЕКЦИИ У БЕРЕМЕННЫХ С САХАРНЫМ ДИАБЕТОМ 1 ТИПА НА ОСЛОЖНЕНИЯ БЕРЕМЕННОСТИ
}

\author{
Иванова Л.А., Алексеенко И.В.
}

ФГБОУ ВО «Кубанский государственный медицинский университет» Минздрава России, Краснодар

ЦЕЛЬ: оценка частоты осложнений беременности у женщин с сахарным диабетом 1 типа при различных вариантах терапии мочевой инфекции.

МАТЕРИАЛЫ И МЕТОДЫ: обследовано 110 беременных с мочевой инфекцией и сахарным диабетом 1 типа. Из них у 38 пациенток пиелонефрит, у 69- бессимптомная бактериурия (ББ), у 3 - цистит. Диагноз мочевой инфекции подтверждался двукратным бактериологическим посевом мочи с интервалом не менее 24 ч. В зависимости от метода лечения мочевой инфекции пациентки были разделены на 3 подгруппы. Подгруппа А (19 человек - пиелонефрит, 23 - ББ) получала антибиотикотерапию и фитопрепарат (золототысячника трава+любистока лекарственного корень+розмарина обыкновенного листья); подгруппа 5 (19 человек - пиелонефрит, 23 - ББ) - только антибиотикотерапию; подгруппа В (23 человека с ББ) только фитотерапию. Статистически значимых различий по количественным параметрам (возраст, ИМТ, дебют и стаж СД, паритет) и по частоте встречаемости осложнений, а также уровню гликогемоглобина в выделенных подгруппах до лечения не было (p>0,05). После лечения оценивалось сохранение осложнений беременности, развившихся на фоне мочевой инфекции: угроза выкидыша, внутриутробное инфицирование плода, протеинурия, анемия, преждевременные роды. Эффективность каждого вида терапии оценивалась с помощью критерия Мак-Немара, достоверность различий в подгруппах $-x^{2}$ Пирсона.

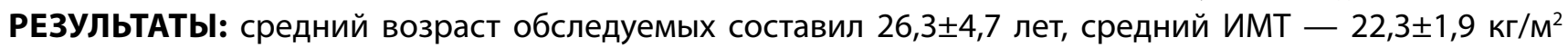
средний уровень гликогемоглобина $-6,2 \pm 0,7 \%$. Как комплексная терапия пиелонефрита (антибиотики с фитопрепаратом), так и монотерапия антибиотиками оказались эффективны в устранении угрозы выкидыша, внутриутробного инфицирования и анемии $(p<0,05)$. Добавление фитопрепарата к антибиотикотерапии при пиелонефрите снижало частоту преждевременных родов по сравнению с монотерапией антибиотиком ( $p=0,038)$, по другим осложнениям различия между подгруппами не получены $(p>0,05)$. При бессимптомной бактериурии комплексная терапия и монотерапия антибиотиком были эффективны в устранении угрозы выкидыша, внутриутробного инфицирования, анемии; монотерапия фитопрепаратом у беременных с диабетом 1 не приводила к ликвидации данных осложнений. Комплексная терапия бессимптомной бактериурии оказалась эффективнее монотерапии антибиотиком в отношении влияния на преждевременные роды $(p=0,035)$ и равноэффективна в отношении угрозы выкидыша, внутриутробного инфицирования и анемии ( $>>0,05)$.

Выводы: добавление фитопрепарата (золототысячника трава+любистока лекарственного корень+розмарина обыкновенного листья) к антибиотикотерапии при пиелонефрите и бессимптомной бактериурии у беременных с диабетом 1 типа с целью профилактики преждевременных родов представляется целесообразным. Монотерапия бессимптомной бактериурии фитопрепаратом (золототысячника трава+любистока лекарственного корень+розмарина обыкновенного листья) у беременных с диабетом 1 типа неэффективна для устранения угрозы выкидыша, внутриутробного инфицирования, анемии, поэтому антибиотики должны назначаться на старте терапии бессимптомной бактериурии.

КЛЮЧЕВЫЕ СЛОВА: сахарный диабет 1 mипа; мочевая инфекция; осложнения беременности. 